\title{
The Progeny test of Friesian sires for milk traits by using the contemporary comparison method
}

La prueba de progenie de toros Friesian para las características de la leche mediante el uso del método de comparación contemporáneo

Mardenli O. The Progeny test of Friesian sires for milk traits by using the contemporary comparison method. Rev Colombiana Cienc Anim. Recia. 2021; 13(1):e747. https://doi.org/10.24188/recia. v13.n1.2021.747

Universidad de Sucre, Colombia

Los autores permiten a RECIA reimprimir el material publicado en él. En caso de que un autor quiera traducir o usar una publicación parcial o completa de nuestro Diario, el autor debe obtener un permiso por escrito del editor de la revista.

Copyright (C) 2021. El (los) autor (es). Este es un artículo de acceso abierto distribuido bajo los términos de Creative Commons Attribution 4.0 (https://creativecommons.org/licenses/by-ncsa/4.0/), El uso, distribución o reproducción está permitido, siempre que se acrediten al autor original y al propietario del copyright y que se cite la publicación original en esta revista, de acuerdo con la práctica académica aceptada. No se permite el uso, distribución o reproducción que no cumpla con estos términos. 


\title{
The Progeny test of Friesian sires for milk traits by using the contemporary comparison method
}

\section{La prueba de progenie de toros Friesian para las características de la leche mediante el uso del método de comparación contemporáneo}

\section{Omar Mardenli}

University of Aleppo, Faculty of Agriculture, Department of Animal

DOI: https://doi.org/10.24188/recia.v13.n1.2021.747

Production, Syria.

omardenli@gmail.com

(D) https://orcid.org/0000-0002-6092-7604

Recepción: 15 junio 2020

Aprobación: 27 Diciembre 2020

Publicación: 3 marzo 2021

\begin{abstract}
In this study, the contemporary comparison method (CC) of half-sibs relation was used to estimate the breeding values of Holstein-Friesian sires for 305 -day milk yield (305-DMY) and basic components of milk traits, 409 records of cows that are daughters of ten sires in eight Syrian dairy farms where used. Result of the study showed differences in the estimated breeding values ( ${ }_{c c}$ EBVs), where the E Sire achieved the highest value of 305-DMY trait (254.47 kg), while the B Sire achieved the highest value of milk protein percentage (MPP), milk fat percentage (MFP)and milk lactose percentage (MLP) traits $(0.822 \%, 0.857 \%$ and $1.09 \%$ respectively). According to their sires, daughters of $E$ Sire outperformed the counterparts in the 305-DMY ( $p=0.001)$, MPP $(p=0.001)$ and MFP $(p=0.04)$ traits $(5701.44 \mathrm{~kg}, 3.55 \%$, and $3.88 \%$ respectively). According to source of farm, daughters in Farm 5 achieved the highest value of 305-DMY trait ( $p=0.04$ ) and daughters in the seventh farm achieved the highest value of MPP trait ( $\mathrm{p}=0.007)$, the values were $5403.48 \mathrm{~kg}$ and $3.54 \%$ respectively. Values of heritability $\left(h^{2}\right)$ for the traits of 305-DMY, MPP, MFP and MLP were 0.33,0.54,0.43 and 0.47 respectively. Most of genetic and phenotypic correlations coefficients were approaching to zero except the genetic relation between MLP and MPP and phenotypic relation between MFP and MPP ( 0.88 and 0.84 respectively).
\end{abstract}

Keywords: Progeny test, breeding values, 305-day milk yield, milk components.

\section{RESUMEN}

En este estudio, se utilizó el método de comparación contemporáneo (CC) de la relación de medio hermanos para estimar los valores genéticos de los toros Holstein-Friesian para 305 días de producción de leche (305-DMY) y componentes básicos de las características de la leche, 409 registros de vacas. que son hijas de diez toros en ocho granjas lecheras sirias donde se utilizaron. El resultado del estudio mostró diferencias en los valores genéticos estimados (ccEBVs), donde el E Sire alcanzó el valor más alto del rasgo 305-DMY $(254,47 \mathrm{~kg})$, mientras que el B Sire alcanzó el mayor valor de porcentaje de proteína de la leche (MPP), leche rasgos de porcentaje de grasa (MFP) y porcentaje de lactosa de la leche (MLP) (0.822\%, $0.857 \%$ y $1.09 \%$ respectivamente). De acuerdo con sus toros, las hijas de E Sire superaron a sus contrapartes en los rasgos 305-DMY ( $\mathrm{p}=0.001)$, MPP ( $\mathrm{p}=0.001)$ y MFP ( $\mathrm{p}=0.04)$ (5701.44 $\mathrm{kg}$, 3.55\% y $3.88 \%$ respectivamente). Según la fuente de la finca, las hijas de la Finca 5 alcanzaron el valor más alto del rasgo 305-DMY ( $\mathrm{p}=0.04)$ y las hijas de la séptima finca lograron el valor más alto del rasgo MPP ( $\mathrm{p}=0.007)$, los valores fueron $5403.48 \mathrm{~kg}$ y $3.54 \%$ respectivamente. Los valores de heredabilidad (h2) para los rasgos de 305-DMY, MPP, MFP y MLP fueron 0.33, 0.54, 0.43 y 0.47 respectivamente. La mayoría de los coeficientes de correlación genéticos y fenotípicos se acercaban a cero, excepto la relación genética entre MLP y MPP y la relación fenotípica entre MFP y MPP (0,88 y 0,84 respectivamente).

Palabras clave: Prueba de progenie; valores genéticos; producción de leche de 305 días; componentes de la leche. 


\section{INTRODUCTION}

"Prediction" or "estimation" of breeding values (EBVs) is considered a very important procedure in the animal breeding and genetic improvement fields of livestock, especially when the main objective of these procedures is to arrange candidates in the herd (e.g., bulls or rams). The progeny test is a method under which the breeding values of an individual are estimated by using the mean of his offspring through half -sibs or full -sibs, or both (1). The CC method represents a significant qualitative advance in the accuracy of genetic assessments because of their ability to take into account the phenotypes which are expressed under environmental conditions (2). Unlike the other common methods, estimation of breeding values based on CC of herd mates method takes into account only one trait and also depends basically on the value of the heritability of the studied trait, but it neglects the economic value of the trait against other traits and does not allow the excellent trait to compensate for the less errant qualities trait in the animal (3). In terms of animal breeding, the method of CC has achieved great benefit, by allowing the artificial insemination centers (AI) to investigate the genetic distinction of bulls whose straws are distributed over a wide geographical area, bypassing countries and continents (4).

It well known, within the various mating systems, Holstein - Friesians have a high superiority in individual and maternal additivity for milk yield (MY) traits $(5,6)$. In literature, many studies have examined the estimation of genetic and nongenetic parameters for daily milk yields (DMY), milk fat yield (MFY), milk protein yield (MPY), milk fat percentages (MFP), milk protein percentages (MPP) and milk lactose percentage (MLP) $(7,8,9,10,11,12)$. The production of the Holstein -Friesian cows of milk varies from country to country and even from one place to another in the same country, according to the welfare standards and prevailing environmental conditions, for example, in Sudan, MY amount reached to $3358 \mathrm{~kg}$ per season (13), while in Sweden the amount reached to $6529 \mathrm{~kg}$ (14) and in Britain reached to $5533 \mathrm{~kg}$ (15).

Hence, the aim of our study was to estimate and evaluate the breeding values of traits of 305-day milk (305 -DMY), milk protein percentage (MPP), milk fat percentage (MFB) and milk lactose percentages (MLP) by using the CC method of herd mates. Also, study the genetic and phenotypic relations and genetic superiority of sires and their performance and effects on the productivity of their daughters in different Syrian dairy farms.

\section{MATERIAL AND METHODS}

Breeding plan, management and chemical analysis of milk components. The study was conducted on the imported Holstein-Friesian breed in Syria. Sires and their daughters, which are under study, were monitored and tracked by records available in eight dairy farms (409 records). The daughters (409 cows) were chosen as a result of the artificial insemination of ten sires (parent stock) according to the term of half-sibs' relation and divided into eight herds according to their distribution across the farms as shown in the following table (Table 1):

Table. 1. Distribution and numbers of daughters according to their sires in different dairy farms.

\begin{tabular}{|c|c|c|c|c|c|c|c|c|c|}
\hline \multirow{2}{*}{ Sires } & \multicolumn{8}{|c|}{ Farm } & \multirow{2}{*}{ Total } \\
\hline & 1 & 2 & 3 & 4 & 5 & 6 & 7 & 8 & \\
\hline A & - & 5 & 4 & 12 & - & 12 & 6 & - & 39 \\
\hline B & 4 & - & - & 9 & 8 & 5 & 9 & - & 35 \\
\hline $\mathrm{C}$ & - & 10 & - & 3 & - & - & 20 & - & 33 \\
\hline D & - & - & - & 25 & - & 13 & - & 5 & 43 \\
\hline E & 6 & - & 5 & 15 & - & 5 & 9 & - & 40 \\
\hline $\mathrm{F}$ & - & - & - & 9 & 8 & 15 & - & - & 32 \\
\hline G & - & - & 21 & 15 & - & - & 7 & - & 43 \\
\hline $\mathrm{H}$ & 12 & - & 7 & 4 & 8 & 9 & - & 12 & 52 \\
\hline I & 10 & 10 & 15 & 9 & - & - & - & - & 44 \\
\hline $\mathrm{J}$ & 13 & 5 & 12 & 8 & - & - & - & 10 & 48 \\
\hline Total & 45 & 30 & 64 & 109 & 24 & 59 & 51 & 27 & \\
\hline \multicolumn{2}{|c|}{ Grand total } & \multicolumn{7}{|c|}{409} & \\
\hline
\end{tabular}

The sires were renumbered and encoded with symbols A, B, C, D, E, F, G, H, I and J. The eight dairy farms were also reencoded according to numbers 1 to 8 . According to the veterinary medical reports, all the studied and selected cows were in good health and most of them completed their first productive season (parity) and were at about the same age $( \pm 6$ month). The cows were kept under different environmental conditions on the farm. Daily cow's rations were balanced according to the Institute National of Research Agronomy feeding system (INRA). All cows were milked twice a day. The amount of milk has been adjusted to 305 days for cows that have not completed their parity according to Van Vleck and 
Henderson (16). Milk samples were collected and analyzed in the third, fifth and ninth months of the parity for each daughter cow. Combined milk from morning and evening milking was placed in a small sterile bottle (100 ml/sample) and supplemented with $2 \mathrm{ml}$ acetone (dimethyl ketone). Basic variables of milk, i.e. fat, protein, and lactose contents were examined on Milkoscan FT-104.

Data and statistical analysis. Data related to 409 records were collected and arranged by a sophisticated computer and subjected to statistical analysis. Least- mean squares of studied traits, variance components, heritability, genetic and phenotypic correlations were calculated according to the statistical method of two-way of unbalanced design according to the Restricted (or Residual, or Reduced) Maximum Likelihood method (REML) based on the following model:

$\mathrm{Y}_{\mathrm{ijk}}=\mu+\alpha+\beta_{\mathrm{ij}}+\mathrm{e}_{\mathrm{ijk}}$

Where:

$\mathrm{Y}_{\mathrm{ijk}}$ is the progeny record k resulting from $\mathrm{j}$ dam which was mated with i sire.

$\mu$ is the overall mean.

$\alpha$ is the random effect of i sire.

$\beta_{\mathrm{ij}}$ is the random effect of $\mathrm{j}$ dam which was inseminated by the i sire.

$\mathrm{e}_{\mathrm{ijk}}$ is the random genetic and phenotypic deviations that resulting from an individual difference within sires (vector of random error) which is presumably $=0$.

The heritability coefficient was calculated according to the following equation:

$h^{2}=\left(4 \sigma_{s}^{2}\right) /\left(\sigma_{s}^{2}+\sigma_{e}^{2}\right)$

Where:

$\sigma_{s}^{2} \quad$ is the genetic variation of the sires.

$\sigma_{s}^{2}+\sigma_{e}^{2}$ is the phenotypic variation of the sires.

The genetic correlation coefficient $\left(\mathrm{r}_{\mathrm{G}}\right)$ was calculated according to the following equation:

$r_{G}=\left(\operatorname{Covxy}_{G)} / \sqrt{ }\left(\sigma^{2} \operatorname{Sx}_{G} \sigma^{2} \operatorname{Sy}_{G}\right)\right.$

Where:

Covxy $_{G}$ is the genetic covariance of traits $\mathrm{X}$ and $\mathrm{Y}$ between sires.

$\sigma^{2} \mathrm{Sx}_{\mathrm{G}}$ is the genetic variance of trait $\mathrm{X}$ between sires.

$\sigma^{2} \mathrm{Sy}_{\mathrm{G}}$ is the genetic variance of trait $\mathrm{Y}$ between sire.

The phenotypic correlation coefficient $\left(r_{p}\right)$ was calculated according to the following equation:

$r_{P}=\operatorname{Covxy}_{P} / \sqrt{ }\left(\sigma^{2} \operatorname{Sx}_{\mathrm{P}} \sigma^{2} \mathrm{Sy}_{\mathrm{P}}\right)$

Where:

$\operatorname{Covxy}_{\mathrm{p}}$ is the phenotypic covariance of traits $\mathrm{X}$ and $\mathrm{Y}$ between sires.

$\sigma^{2} \mathrm{Sx}_{\mathrm{p}}$ is the phenotypic variance of trait $\mathrm{X}$ between sires.

$\sigma^{2} \mathrm{Sy}_{\mathrm{P}}$ is the phenotypic variance of trait Y between sire.

The breeding value of sires (EBV)was assessed in CC method according to the following general equation:

${ }_{\text {cc }} \mathrm{EBV}=2(\mathrm{STA})=2(\mathrm{SGD})(\mathrm{b})$

Where:

STA is the Sire Transmitting Ability.

SGD is the Sire Genetic Deviation.

$\left.\mathrm{SGD}=\sum(\mathrm{D})(\mathrm{n})\right) /\left(\sum \mathrm{W}\right)=\left(\sum(\mathrm{D})\left(\left(\mathrm{X}_{\mathrm{c}}-\mathrm{X}_{\mathrm{h}}\right) /\left(\sum \mathrm{W}\right)\right.\right.$

$\mathrm{X}_{c}$ is the mean of the trait of daughters of studied sire.

$\mathrm{X}_{\mathrm{h}}$ is the mean of the trait of daughters of rest sires.

$\mathrm{W}$ is the coefficient of weight. 
$\mathrm{W}=\left(\mathrm{n}_{1} \mathrm{n}_{2}\right) /\left(\mathrm{n}_{1}+\mathrm{n}_{2}\right)$

$\mathrm{n}_{1}$ is the total number of daughters of studied sire.

$\mathrm{n}_{2}$ is the total number of daughters of the rest sires.

$\mathrm{b}$ is a slope relating to sire and the mean of $\mathrm{n}$ of its offspring.

$\mathrm{b}=\left(\mathrm{h}^{2}\right)\left(\sum \mathrm{W}\right) /\left(4+\left(\sum \mathrm{W}-1\right) \mathrm{h}^{2}\right)$

Duncan's multiple range test (DMRT) was used for multiple comparisons of each trait (17). The data were analyzed using the SAS 9.2 statistical package (18).

\section{RESULTS}

According to the relationship between sires and half-sibs offspring in the herd, the fifth sire daughters (E Sire) outperformed their counterparts in the 305-DMY trait $(p=0.001)$, MPP $(p=0.001)$ and MFP $(p=0.04)$ where the values of least mean -squares were $5701.44 \mathrm{~kg}, 3.55$, and 3.88\% respectively (Table 2). As for MLP trait, the rates of this trait were very similar across the groups of daughters and ranged from 4.76 (B Sire) to 4.80 (C Sire) with no significant difference. According to the daughters's distribution in different farms, the highest value of 305-DMY was in Farm 5 ( $p=0.04$ ), followed by the Farm 1 (5403.48 and $5335.07 \mathrm{~kg}$ respectively), while the quantities were very close to each other in the rest of the farms. Daughters in Farm 7 achieved the highest value in MPP trait $(p=0.007)$ followed by the order Farms 3 and $5(3.54,3.48$ and 3.48\% respectively). As for the rest traits, no significant differences were noticed among groups of daughters (Table 2).

Table.2. Least-square means and standard error (se) of 305 -DMY (kg), MPP, MFP and MLP of daughters according to their sires and farm.

\begin{tabular}{|c|c|c|c|c|}
\hline \multirow{2}{*}{ Source } & 305 -DMY (kg) ${ }^{1}$ & $\mathbf{M P P}^{2}$ & MFP $^{3}$ & MLP $^{4}$ \\
\hline & Mean \pm se & Mean \pm se & Mean \pm se & Mean \pm se \\
\hline Sires & $*$ & $*$ & $* *$ & ns \\
\hline $\mathbf{A}$ & $5277.09^{\mathrm{BC}} \pm 41.49$ & $3.46^{\mathrm{BCD}} \pm 0.01$ & $3.87^{\mathrm{AB}} \pm 0.02$ & $4.77 \pm 0.01$ \\
\hline B & $5212.60^{\mathrm{BC}} \pm 43.43$ & $3.43^{\mathrm{D}} \pm 0.02$ & $3.82^{\mathrm{C}} \pm 0.02$ & $4.76 \pm 0.01$ \\
\hline C & $5179.61^{\mathrm{BC}} \pm 50.47$ & $3.44^{\mathrm{BCD}} \pm 0.02$ & $3.86^{\mathrm{ABC}} \pm 0.02$ & $4.80 \pm 0.01$ \\
\hline D & $5242.87^{\mathrm{BC}} \pm 41.69$ & $3.51^{\mathrm{BC}} \pm 0.01$ & $3.81^{\mathrm{C}} \pm 0.02$ & $4.78 \pm 0.01$ \\
\hline $\mathbf{E}$ & $5701.44^{A} \pm 40.87$ & $3.55^{\mathrm{A}} \pm 0.01$ & $3.88^{\mathrm{A}} \pm 0.02$ & $4.78 \pm 0.01$ \\
\hline $\mathbf{F}$ & $5277.52^{\mathrm{B}} \pm 48.06$ & $3.42^{\mathrm{D}} \pm 0.02$ & $3.85^{\mathrm{ABC}} \pm 0.02$ & $4.77 \pm 0.01$ \\
\hline G & $5295.63^{\mathrm{BC}} \pm 41.94$ & $3.43^{\mathrm{CD}} \pm 0.01$ & $3.83^{\mathrm{BC}} \pm 0.02$ & $4.77 \pm 0.01$ \\
\hline H & $5261.25^{\mathrm{B}} \pm 35.95$ & $3.47^{\mathrm{CD}} \pm 0.01$ & $3.84^{\mathrm{ABC}} \pm 0.01$ & $4.78 \pm 0.01$ \\
\hline I & $5215.15^{\mathrm{BC}} \pm 40.18$ & $3.47^{\mathrm{CD}} \pm 0.01$ & $3.85^{\mathrm{ABC}} \pm 0.02$ & $4.79 \pm 0.01$ \\
\hline $\mathbf{J}$ & $5159.57^{c} \pm 37.90$ & $3.53^{\mathrm{AB}} \pm 0.01$ & $3.83^{\mathrm{BC}} \pm 0.02$ & $4.77 \pm 0.01$ \\
\hline Farm & $* *$ & $* * *$ & ns & ns \\
\hline 1 & $5335.07^{\mathrm{AB}} \pm 39.75$ & $3.41^{\mathrm{B}} \pm 0.02$ & $3.84 \pm 0.02$ & $4.79 \pm 0.01$ \\
\hline 2 & $5240.91^{\mathrm{c}} \pm 48.79$ & $3.46^{\mathrm{B}} \pm 0.02$ & $3.83 \pm 0.02$ & $4.76 \pm 0.01$ \\
\hline 3 & $5220.42^{\mathrm{BC}} \pm 34.44$ & $3.48^{\mathrm{AB}} \pm 0.02$ & $3.85 \pm 0.01$ & $4.79 \pm 0.01$ \\
\hline 4 & $5217.92^{\mathrm{BC}} \pm 24.53$ & $3.47^{\mathrm{AB}} \pm 0.01$ & $3.85 \pm 0.01$ & $4.76 \pm 0.01$ \\
\hline 5 & $5403.48^{A} \pm 54.66$ & $3.48^{\mathrm{B}} \pm 0.03$ & $3.83 \pm 0.02$ & $4.78 \pm 0.02$ \\
\hline 6 & $5266.26^{\mathrm{AB}} \pm 35.11$ & $3.46^{\mathrm{AB}} \pm 0.02$ & $3.86 \pm 0.01$ & $4.78 \pm 0.01$ \\
\hline 7 & $5276.30^{\mathrm{AB}} \pm 39.36$ & $3.54^{\mathrm{A}} \pm 0.02$ & $3.84 \pm 0.02$ & $4.77 \pm 0.01$ \\
\hline 8 & $5297.79^{\mathrm{BC}} \pm 51.90$ & $3.46^{\mathrm{AB}} \pm 0.02$ & $3.85 \pm 0.02$ & $4.78 \pm 0.02$ \\
\hline
\end{tabular}

Means with different superscript are different at assigned specific probability, *: $\mathrm{p}=0.001,{ }^{* *}: \mathrm{p}=0.04, * * *$ : $\mathrm{p}=0.007$, ns: not significant, 305-DMY1: 305-Day Milk Yield (kg), MPP2: Milk Protein Percentage, MFP ${ }^{3}$ : Milk Fat Percentage, MLP ${ }^{4}$ : Milk Lactose Percentage. 
The values of heritability $\left(h^{2}\right)$ of 305-DMY, MPP, MFP and MLP traits at daughters were 0.33,0.54,0.43 and 0.47 respectively (Table 3), while the values of genetic correlation coefficients were very low and negative in general except the correlation between MPP and MLP (0.88). Most of the phenotypic correlations among studied traits were also very low except the correlation between MPP and MFP (0.84).

Table. 3. Values of heritabilities $\left(h^{2}\right)$, genetic correlation coefficients (above the diagonal) and phenotypic correlation coefficients (below the diagonal) of 305-DMY, MPP, MFP and MLP traits across groups of daughters.

\begin{tabular}{ccccc}
\hline & 305-DMY $^{1}$ & MPP $^{2}$ & MFP $^{3}$ & MLP $^{\mathbf{4}}$ \\
\hline 305-DMY & $\mathbf{0 . 3 3}$ & -0.51 & -0.22 & -0.13 \\
MPP & -0.0002 & $\mathbf{0 . 5 4}$ & 0.058 & 0.88 \\
MFP & -0.0000007 & 0.84 & $\mathbf{0 . 4 3}$ & -0.25 \\
MLP & 0.0004 & -0.0000005 & 0.17 & $\mathbf{0 . 4 7}$ \\
\hline
\end{tabular}

05-DMY¹: 305-Day Milk Yield (kg), MPP²: Milk Protein Percentage, MFP3: Milk Fat Percentage, MLP4: Milk Lactose Percentage 3

The contents of Table 4 show the values of SGD, STA and ${ }_{\text {cc }}$ EBV of 305 -DMY (kg) for groups of sires daughters, where the fifth sire daughters (E Sire) outperformed their contemporary mates in these values (184.4 ,127.23 and $254 \mathrm{~kg}$ respectively) followed by the order the daughters of A Sire (85.97,63.62 and 127.24 kg respectively).

Table.4. Values of b, SGD, STA and ${ }_{c c}$ EBV of $305-\mathrm{DMY}^{1}(\mathrm{~kg})$ trait for groups of sires daughters

\begin{tabular}{ccccc}
\hline Sires & $\mathbf{b}^{\mathbf{2}}$ & $\mathbf{S G D}^{\mathbf{3}}$ & $\mathbf{S T A}^{4}$ & ${ }_{\mathbf{c c}} \mathbf{E B V}^{\mathbf{5}}$ \\
\hline A & 0.74 & 85.97 & 63.62 & 127.24 \\
B & 0.71 & -53.895 & -75.652 & -151.303 \\
C & 0.66 & -4.741 & -7.168 & -14.336 \\
D & 0.75 & -2.712 & -3.615 & -7.229 \\
E & 0.69 & 184.4 & 127.23 & 254.47 \\
F & 0.69 & 72.94 & 50.33 & 100.66 \\
G & 0.75 & -38.18 & -28.63 & -57.27 \\
H & 0.63 & -4.053 & -6.440 & -12.881 \\
I & 0.70 & -3.294 & -4.688 & -9.376 \\
J & 0.68 & -3.635 & -5.359 & -10.718 \\
\hline
\end{tabular}

$305-$ DMY $^{1}:$ 305-day milk yield (kg), b²: the weight coefficient slope, SGD 3 : Sire Genetic Deviation, STA Sire Transmitting Ability, EBV $^{5}$ : contemporary comparison Estimated Breeding Value.

As for MPP trait, it has been noticed that daughter of B Sire achieved the highest values of SGD, STA and EBV comparing to other groups $(0.33,0.411$ and $0.822 \%$ respectively), while the rest of the values were very close to zero only a little for the rest of the daughters (Table 5).

Table.5. Values of b, SGD, STA and ${ }_{c c}$ EBV of MPP ${ }^{1}$ trait for groups of sires daughters

\begin{tabular}{|c|c|c|c|c|}
\hline Sires & $\mathbf{B}^{2}$ & SGD $^{3}$ & STA $^{4}$ & $\mathrm{EBV}^{5}$ \\
\hline A & 0.83 & -0.010 & -0.012 & -0.025 \\
\hline B & 0.81 & 0.333 & 0.411 & 0.822 \\
\hline $\mathrm{C}$ & 0.77 & -0.001 & -0.002 & -0.003 \\
\hline D & 0.84 & 0.001 & 0.001 & 0.003 \\
\hline $\mathrm{E}$ & 0.79 & 0.008 & 0.010 & 0.020 \\
\hline $\mathrm{F}$ & 0.79 & -0.003 & -0.004 & -0.008 \\
\hline G & 0.84 & -0.003 & -0.003 & -0.006 \\
\hline $\mathrm{H}$ & 0.75 & 0.002 & 0.002 & 0.004 \\
\hline I & 0.80 & 0.000 & 0.000 & -0.001 \\
\hline $\mathrm{J}$ & 0.79 & 0.003 & 0.004 & 0.008 \\
\hline
\end{tabular}




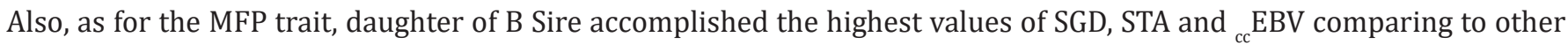
groups $(0.32,0.42$ and $0.857 \%$ respectively), while the rest of the values were also very close to zero only a little (Table 6 ). The values of SGD, STA and ${ }_{c c}$ EBV at the same sire daughters (B Sire) rose slightly relative to the MLP trait, the values were $0.429,0.545$ and $1.09 \%$ respectively (Table 7).

Table.6. Values of b, SGD, STA and ${ }_{c c}$ EBV of MFP $^{1}$ trait for groups of sires daughters

\begin{tabular}{ccccc}
\hline Sires & $\mathbf{b}^{\mathbf{2}}$ & $\mathbf{S G D}^{\mathbf{3}}$ & $\mathbf{S T A}^{\mathbf{4}}$ & ${ }_{\mathrm{cc}} \mathbf{E B V}^{\mathbf{5}}$ \\
\hline A & 0.79 & 0.020 & 0.025 & 0.051 \\
B & 0.76 & 0.329 & 0.429 & 0.857 \\
C & 0.72 & 0.001 & 0.001 & 0.002 \\
D & 0.80 & -0.001 & -0.002 & -0.004 \\
E & 0.75 & 0.003 & 0.004 & 0.008 \\
F & 0.75 & 0.000 & 0.000 & 0.001 \\
G & 0.80 & -0.001 & -0.002 & -0.003 \\
H & 0.69 & 0.000 & 0.001 & 0.001 \\
I & 0.76 & 0.002 & 0.002 & 0.004 \\
J & 0.74 & -0.001 & -0.001 & -0.001 \\
\hline
\end{tabular}

MFP $^{1}$ : milk fat percentage, $b^{2}$ : the weight coefficient slope, SGD $^{3}$ : Sire Genetic Deviation, STA ${ }^{4}$ Sire Transmitting Ability, ${ }_{\text {cc }}$ BVV $^{5}$ : contemporary comparison Estimated Breeding Value

The values of SGD, STA and ${ }_{c c}$ EBV at the same sire daughters (B Sire) rose slightly relative to the MLP trait, the values were $0.429,0.545$ and $1.09 \%$ respectively (Table 7 ).

Table.7. Values of b, SGD, STA and ${ }_{c c}$ EBV of MLP' ${ }^{1}$ trait for groups of sires daughters

\begin{tabular}{ccccc}
\hline Sires & $\mathbf{b}^{\mathbf{2}}$ & $\mathbf{S G D}^{\mathbf{3}}$ & $\mathbf{S T A}^{4}$ & ${ }_{\mathrm{cc}} \mathbf{E B V}^{\mathbf{5}}$ \\
\hline A & 0.81 & 0.002 & 0.002 & 0.004 \\
B & 0.78 & 0.429 & 0.545 & 1.091 \\
C & 0.74 & 0.017 & 0.023 & 0.046 \\
D & 0.82 & 0.003 & 0.003 & 0.006 \\
E & 0.76 & 0.001 & 0.001 & 0.003 \\
F & 0.77 & -0.002 & -0.002 & -0.005 \\
G & 0.82 & -0.005 & -0.007 & -0.013 \\
H & 0.72 & 0.015 & 0.021 & 0.041 \\
I & 0.78 & 0.013 & 0.017 & 0.033 \\
J & 0.76 & -0.007 & -0.010 & -0.019 \\
\hline
\end{tabular}

MLP$^{1}$ : milk lactose percentage, $b^{2}$ : the weight coefficient slope, SGD ${ }^{3}$ : Sire Genetic Deviation, STA ${ }^{4:}$ Sire Transmitting Ability, ${ }_{c c} E V^{5}$ : contemporary comparison Estimated Breeding Value.

\section{DISCUSSION}

In fact, there is a great diversity in the methods that are concerned with estimating the breeding values of sires for the various productive and reproductive traits, but these methods differ greatly among them in terms of principle, requirements, style and resulting values taking into consideration the advantages and disadvantages of each method. The CC method is not a basic substitute for conventional animal breeding but can be a powerful complement.

In the current study, it was noted that the daughters of the fifth sire (E Sire) excelled in the ${ }_{c c}$ EBV of the 305 -DMY trait where the value exceeded the general production level by $254 \mathrm{~kg}$ (Table 4) followed by the order the daughters of A and F Sires with a difference didn't exceed $155 \mathrm{~kg}$. This was accompanied by a superiority in the same path in the 305 -DMY trait for the same sires mentioned (Table 2) supported by the estimated high value of heritability coefficient (Table 3) for this trait. But the ${ }_{c c}$ EBV of MPP, MFP and MLP traits were outperformed by the daughters of B Sire. The estimates of milk production in first lactation parity for 305 -DMY in our study (Table 2) were lower than those reported by Buckley et al (19) and Pritchard et al (20) who reported that 305 -DMY of Holstein-Friesian breed were $6557 \mathrm{~kg}$ and $7480.06 \mathrm{~kg}$, respectively. MPP and MFP in our study (Table 2) were little close to the values attained by Calus et al (21) in Australian Friesian (MFP 3.87\%) and by Gorjanc et al (22) in Brown Swiss (MFP 3.89\%, MPP 3.22\%) and Slovenian Simmental (MFP 
3.92\%, MPP 3.26\%). While MLP values in our study were lower than the value $5.12 \%$ that were attained by Sneddon et al (7). With regard to our findings on genetic and phenotypic correlations, they were very similar to those of Sneddon et al (7) while the values of heritabilities were lower than those in our study, where the values for305-DMY, MPP, MFP and MLP traits were $0.22,0.32,0.35$ and 0.25 respectively. Also, the heritabilities were less than our findings for those reported by Welper and Freeman (23), Roman et al (9) and Pryce and Harris (11).

Our mentioned results indicate that there is a clear genetic superiority among the studied sires, on the other hand, there were also a clear difference in the amounts of studied traits based on source of farm, although the amount of milk decreased relatively compared to the random factor source (sire) in daughters in different groups. Many studies emphasized the role of environmental factors, farm, health, nutritional conditions and management in the productive and reproductive performance of cows which in the end either increases or decreases production $(24,25)$. According to basic principle of CC method which includes the study of one independent trait in estimation, we find that the daughters of sires, whose breeding values were declining in the traits of 305 -DMY, have excelled in the breeding values of other traits, where the daughters of B Sire have excelled in the MPP, MFP and MLP traits (Tables 5,6 and 7). In general, according to the multiple relationships that dominate the different traits of the milk product and its components such as genetic, phenotypic and environmental correlations, it is granted, that this leads to different breeding values. Some important considerations may be the reason for the low productivity of cows in the first lactation parity in our study, where cows in the first lactation parity of production cannot fully show their genetic abilities, cows may be incomplete growth or their organs are not developed to the extent required (26). Despite the modest performance of daughters in the first productive parity, this gives a very basic and important consideration in the process of selecting sires, as it is expected that productivity among daughters will rise significantly to high levels in the subsequent productive parities, taking into account the mating system that occur within the breed, such as inbreeding, it is necessary looking at the rates of mating, which may give rise to some problems generated by the homozygosity (27). Anyway, the wide range in the EBV of the 305 -DMY trait of the studied sires gives an impression about the wide range of additive genetic variation, which is very important in the selection programs, thus, setting a strategy for the genetic improvement processes by preserving the superior sires and their daughters in order to benefit from their offspring later for the purpose of herd sustainability and carrying out the replacements in an appropriate way. In our study, an opposing relationship has been emerged during the rise in the breeding values of MPP, MFP and MLP traits and the decrease in those values for the 305 -DMY trait or the contrary at daughters of studied sires. In most literature studies, generally, this opposing may create a kind of controversy and preference for these traits among breeders, some food industrial establishments, or even the government institutions plan. Where the goal, sometimes, is to plan to acquire manufacturing destinations such as cheese and butter, or otherwise, depending on the economic value and prices of milk and its components and yield size (28).

In conclusions from the current study, it was concluded that there was a clear difference in ${ }_{c c}$ EBVs and high differences in additive genetic variation among the studied traits of milk and its composition that can be used in the process of subsequent selection and other breeding purposes.

\section{REFERENCES}

1. Renand G. Genetic parameters of French beef breeds used in crossbreeding for young bull production. II - Slaughter performance, Genet. Sel. Evol. 1985; 17(2):265-282. https://www.ncbi.nlm.nih.gov/pmc/articles/PMC2713923/

2. Robertson A, Stewart A, Ashton ED. The progeny assessment of dairy sires for milk: The use of contemporary comparisons. Proc Br Soc Anim Prod. 1956; 43-50. https://doi.org/10.1017/S0369852100001688

3. Henderson CR, Carter HW, Godfrey JT. Use of the contemporary average in appraising progeny test of dairy bulls. J Anim Sci. 1954; 12:949. https://digitalcommons.unl.edu/cgi/viewcontent.cgi?article=1031\&context=wcgalp

4. Weigel KA, VanRaden PM, Norman HD, Grosu H. A 100-Year Review: Methods and impact of genetic selection in dairy cattle -From daughter- dam comparisons to deep learning algorithms. J Dairy Sci. 2017; 100(12):10234-10250. https://doi.org/10.3168/jds.2017-12954

5. Robison OW, Mcdaniel BT, Rincon EJ. Estimation of direct and maternal additive and heterotic effects from crossbreeding experiments in animals. J Anim Sci. 1981; 52(1):44-50. https://doi.org/10.2527/jas1981.52144x 
6. Thorpe W, Kangethe P, Rege JEO, Mosi RO, Mwandotto BAJ, Njuguna P. Crossbreeding Ayrshire, Friesian and Sahiwal cattle for milk yield and preweaning traits of progeny in the semiarid tropics of Kenya. J Dairy Sci. 1993; 76(7): 2001-2012. https://doi.org/10.3168/jds.S0022-0302(93)77534-7

7. Sneddon NW, Lopez-Villalobos N, Hickson RE, Shalloo L. Genetic parameters for lactose and its relationship with concentrations and ratios of other milk components. Proceedings of the New Zealand Society of Animal Production. 2012; 72:76-80. http://www.nzsap.org/system/files/proceedings/2012/ab12018.pdf

8. Roman RM, Wilcox CJ, Littell RC. Genetic trends for milk yield of Jerseys and correlated changes in productive and reproductive performance. J Dairy Sci. 1999; 82:196-204. https://www.nrcresearchpress.com/d voi/ pdfplus/10.4141/cjas79-024

9. Roman RM, Wilcox CJ. Bivariate animal model estimates of genetic, phenotypic, and environmental correlations for production, reproduction, and somatic cell in Jerseys. J Dairy Sci. 2000; 83:829-835. https://www.sciencedirect. com/science/article/pii/S0022030200749460

10. Johnson DL, Petch SF, Winkelman AM, Bryant M. Genetics of milk characteristics in New Zealand dairy cattle. Proceedings of the New Zealand Society of Animal Production. 2000; 60:318-319. http://www.nzsap.org/ proceedings/2000/genetics-milk-characteristics-new-zealand-dairy-cattle

11. Pryce JE, Harris BL. Genetics of body condition score in New Zealand dairy cows. J Dairy Sci. 2006. 89:4424-4432. https://www.journalofdairyscience.org/article/S0022-0302(06)72490-0/fulltext

12. Miglior F, Sewalem A, Jamrozik J, Bohmanova J, Lefebvre DM, Moore RK. Genetic analysis of milk urea nitrogen and lactose and their relationships with other production traits in Canadian Holstein cattle. J Dairy Sci. 2007; 90: 2468-2479. https://www.ncbi.nlm.nih.gov/pubmed/17430951

13. Amasaib EO, Mohamed HE, Fadel Elseed AN. Lactation Length and Lactation Milk Yield in Cattle in Sudan. J Dairy Sci. 2008; 2(1):1-4. http://medwelljournals.com/abstract/?doi=rjdsci.2008.1.4

14. Bratt G. Milk Kontorllen 1984-1985. New Progress. Kontorllen 1984-1985 Nya framsteg. Husdjur (1985). No. 10:710 (SV) SHS. Hollsta. Sweden Anim Breed Abstr. 1985; 54:208.

15. Ditton T. Federation of UK milk marketing Boards. UK dairy facts and figures, xiii. Anim Breed Abst. 1985; 54:210.

16. Van Vleck LD, Henderson CR. Ratio factors for adjusting monthly test-day data for age and season of calving and ratio factors for extending part lactation records. J Dairy Sci. 1961; 44:1093-1101. https://www.journalofdairyscience. org/article/S0022-0302(61)89860-3/abstract

17. Gomez KA, Gomez AA. Statistical Procedures for Agricultural Research. 2nd Edition, John Wiley and Sons, New York. $1984 \quad$ https://www.scirp.org/(S(lz5mqp453edsnp55rrgjct55))/reference/ReferencesPapers. aspx?ReferenceID=2253909

18. SAS.SAS/STAT Users Guide for Personal Computers Release 9. 2.SAS. Institute Inc., Cary, NC., USA: 2004. https:// support.sas.com/documentation/onlinedoc/91pdf/sasdoc 91/ets ug 7314.pdf

19. Buckley, F., Sullivan, K. O, Mee, J. F., Evans, R. D., Dillon, P. 2003. Relationships among milk yield, body condition, cow weight and reproduction in spring-calved Holstein-Friesians. J Dairy Sci. 86(7):2308-2319. https://www. journalofdairyscience.org/article/S0022-0302(03)73823-5/fulltext

20. Pritchard T, Coffey M, Mrode R, Wall E. Genetic parameters for production, health, fertility and longevity traits in dairy cows. J Dairy Sci. 2013; 7(1):34-46. https://www.ncbi.nlm.nih.gov/pubmed/23031504

21. Calus MPL, Carrick MJ, Veerkamp RF, Goddard ME. Estimation of genetic parameters for milk fat depression in dairy cattle. J Dairy Sci. 2005; 88:1166-1177. https://www.sciencedirect.com/science/article/pii/S0022030205727831 
22. Gorjanc G, Malovrh S, Logar B, Kovac M. Fixed effects for 305-day lactation milk traits in cattle. Zbornik Biotehniške Fakultete Univerze V Ljubljani Kmetijstvo Supliment. 2001; 31, 301-307. https://www.scribd.com/ document/2551877/Fixed-effects-for-305-day-lactation-milk-traits-in-cattle

23. Welper RD, Freeman AE. Genetic parameters for yield traits of Holsteins, including lactose and somatic cell score. J Dairy Sci. 1992. 75:1342-1348. https://www.sciencedirect.com/science/article/pii/S0022030292778850

24. Fox PF, Morrissey PA. Review of the progress of dairy science: the heat stability of milk. J Dairy Res. $1977 ; 44: 627$. https://www.cambridge.org/core/journals/journal-of-dairy-research/article/heat-stability-of- milk

25. Ng-Kwai-Hang KF, Hayes JF, Moxley JE, Monardes HG. Environmental influences on protein content and composition of bovine milk. J Dairy Sci; 1982; 65:1993. https://www.ncbi.nlm.nih.gov/pubmed/6890960

26. Migose SA, Magothe TM, Muasya TK, Ilatsia EDA, Kahi K. Milk production and reproductive performance of Bos Taurus dairy breeds in Kenya. In: Proceedings of the 32nd Scientific Conference of the Tanzania Society of Animal Production. 2006. 32:184-190.

27. Liesbeth VW. Textbook Animal Breeding and Genetics for BSc students. Centre for Genetic Resources the Netherlands and Animal Breeding and Genomics Centre, Groen 2015. https://www.wur.nl/upload_mm/d/b/b/614bcc19-036f434e-9d40-609364ab26da Textbook\%20Animal\%20Breeding\%20and\%20Genetics-v17-20151122 1057.pdf

28. Cardoso VL, Pereira Lima ML, Nogueira JR, de Carneiro RLR, Sesana RC, Oliveira EJ, Faro LE. Economic values for milk production and quality traits in south and southeast regions of Brazil. R Bras Zootec. 2014; 43(12):636-642. https://doi.org/10.1590/S1516-35982014001200002 